\title{
Nitrogen attenuation of terrestrial carbon cycle response to global environmental factors
}

\author{
Atul Jain, ${ }^{1}$ Xiaojuan Yang, ${ }^{1}$ Haroon Kheshgi, ${ }^{2}$ A. David McGuire, ${ }^{3}$ \\ Wilfred Post, ${ }^{4}$ and David Kicklighter ${ }^{5}$ \\ Received 21 March 2009; revised 29 June 2009; accepted 5 August 2009; published 30 December 2009.
}

[1] Nitrogen cycle dynamics have the capacity to attenuate the magnitude of global terrestrial carbon sinks and sources driven by $\mathrm{CO}_{2}$ fertilization and changes in climate. In this study, two versions of the terrestrial carbon and nitrogen cycle components of the Integrated Science Assessment Model (ISAM) are used to evaluate how variation in nitrogen availability influences terrestrial carbon sinks and sources in response to changes over the 20th century in global environmental factors including atmospheric $\mathrm{CO}_{2}$ concentration, nitrogen inputs, temperature, precipitation and land use. The two versions of ISAM vary in their treatment of nitrogen availability: ISAM-NC has a terrestrial carbon cycle model coupled to a fully dynamic nitrogen cycle while ISAM-C has an identical carbon cycle model but nitrogen availability is always in sufficient supply. Overall, the two versions of the model estimate approximately the same amount of global mean carbon uptake over the 20th century. However, comparisons of results of ISAM-NC relative to ISAM-C reveal that nitrogen dynamics: (1) reduced the 1990s carbon sink associated with increasing atmospheric $\mathrm{CO}_{2}$ by $0.53 \mathrm{PgC} \mathrm{yr}^{-1}\left(1 \mathrm{Pg}=10^{15} \mathrm{~g}\right)$, (2) reduced the 1990s carbon source associated with changes in temperature and precipitation of $0.34 \mathrm{PgC} \mathrm{yr}^{-1}$ in the $1990 \mathrm{~s}$, (3) an enhanced sink associated with nitrogen inputs by $0.26 \mathrm{PgC} \mathrm{yr}^{-1}$, and (4) enhanced the 1990s carbon source associated with changes in land use by $0.08{\mathrm{PgC} \mathrm{yr}^{-1}}^{-}$in the $1990 \mathrm{~s}$. These effects of nitrogen limitation influenced the spatial distribution of the estimated exchange of $\mathrm{CO}_{2}$ with greater sink activity in high latitudes associated with climate effects and a smaller sink of $\mathrm{CO}_{2}$ in the southeastern United States caused by $\mathrm{N}$ limitation associated with both $\mathrm{CO}_{2}$ fertilization and forest regrowth. These results indicate that the dynamics of nitrogen availability are important to consider in assessing the spatial distribution and temporal dynamics of terrestrial carbon sources and sinks.

Citation: Jain, A., X. Yang, H. Kheshgi, A. D. McGuire, W. Post, and D. Kicklighter (2009), Nitrogen attenuation of terrestrial carbon cycle response to global environmental factors, Global Biogeochem. Cycles, 23, GB4028, doi:10.1029/2009GB003519.

\section{Introduction}

[2] Constraints of the nitrogen $(\mathrm{N})$ cycle on carbon $(\mathrm{C})$ uptake in response to increasing atmospheric $\mathrm{CO}_{2}$ concentrations $\left(\left[\mathrm{CO}_{2}\right]\right)$ has been proposed as an important factor in controlling terrestrial $\mathrm{CO}_{2}$ sinks, a concept referred to as progressive N limitation [Hungate et al., 2003; Luo et al., 2004]. The terrestrial $\mathrm{N}$ cycle also has the potential to

\footnotetext{
${ }^{1}$ Department of Atmospheric Sciences, University of Illinois at UrbanaChampaign, Urbana, Illinois, USA.

${ }^{2}$ ExxonMobil Research and Engineering Company, Annandale, New Jersey, USA.

${ }^{3}$ U.S. Geological Survey, Alaska Cooperative Fish and Wildlife Research Unit, University of Alaska Fairbanks, Fairbanks, Alaska, USA.

${ }^{4}$ Environmental Sciences Division, Oak Ridge National Laboratory, Oak Ridge, Tennessee, USA.

${ }^{5}$ Marine Biological Laboratory, Woods Hole, Massachusetts, USA.

Copyright 2009 by the American Geophysical Union. 0886-6236/09/2009GB003519\$12.00
}

interact with terrestrial $\mathrm{C}$ cycle responses to changes in climate, $\mathrm{N}$ inputs and land use [Canadell et al., 2007].

[3] Observations from open top chamber, greenhouse and Free-Air Concentration Enrichment (FACE) experiments suggest that terrestrial ecosystems grown under elevated $\left[\mathrm{CO}_{2}\right]$ require more $\mathrm{N}$ to support enhanced plant growth than is required at ambient $\mathrm{CO}_{2}$ [Luo et al., 2006]. This is because increased $\mathrm{C}$ storage in vegetation and soil causes $\mathrm{N}$ to be sequestered in organic matter, leading to a decrease of plant-available soil mineral $\mathrm{N}$ and constrains $\mathrm{C}$ sequestration in terrestrial ecosystems over time [Luo et al., 2004].

[4] The $\mathrm{N}$ cycle may also influence the responses of the $\mathrm{C}$ cycle to climate change. Warmer and wetter soils have the potential to increase the amount of inorganic $\mathrm{N}$ in soil through enhanced mineralization associated with decomposition. The improved nitrogen availability may lead to enhanced productivity. Although soil microbial activity and the $\mathrm{N}$ needs of soil organisms are also increased during this process, the enhanced mineralization of $\mathrm{N}$ by increased 
soil microbial activity generally increases plant-available $\mathrm{N}$ in addition to meeting the $\mathrm{N}$ needs of soil organisms. The mineralization of soil $\mathrm{N}$ associated with decomposition has the potential to enhance the uptake of $\mathrm{CO}_{2}$ by vegetation more than the loss of $\mathrm{CO}_{2}$ from decomposition [Shaver et al., 1992; McGuire et al., 2007].

[5] Models generally featured in the IPCC's third [Prentice et al., 2001] and fourth [Denman et al., 2007] assessment reports, as well as the recent coupled climate $\mathrm{C}$ cycle intercomparison project, $\mathrm{C}^{4} \mathrm{MIP}$ [Friedlingstein et al., 2006] did not account for the $\mathrm{C}-\mathrm{N}$ interactions and Hungate et al. [2003] estimated that there would be insufficient $\mathrm{N}$ available to support the magnitude of global $\mathrm{C}$ uptake estimated by these unconstrained models. The concern raised by Hungate et al. [2003], therefore, implies that neglecting $\mathrm{C}-\mathrm{N}$ interactions results in overestimates of the terrestrial biosphere's uptake of $\mathrm{CO}_{2}$ over the 21 st century. This concern is supported by several process-based modeling studies [McGuire et al., 1997; Kicklighter et al., 1999; Thornton et al., 2007, 2009; Sokolov et al., 2008], which have already investigated how the $\mathrm{N}$ cycle influences future responses of the global terrestrial $\mathrm{C}$ cycle to increasing $\left[\mathrm{CO}_{2}\right]$ and noted nitrogen constraints on the potential for $\mathrm{CO}_{2}$ fertilization to increase future terrestrial carbon storage. Furthermore, two recent studies [Sokolov et al., 2008; Thornton et al., 2009] find that consideration of nitrogen dynamics alters the modeled response of terrestrial carbon dynamics to future climate change. In simulations that do not consider $\mathrm{C}-\mathrm{N}$ interactions, they found that global warming always reduces terrestrial carbon storage. However, when $\mathrm{C}-\mathrm{N}$ interactions are included, they find that their modeled terrestrial carbon storage actually increases with moderate increases in temperature. In addition to $\left[\mathrm{CO}_{2}\right]$ and climate normally considered in global change studies, terrestrial carbon storage may also be influenced by atmospheric $\mathrm{N}$ deposition and land use change.

[6] Atmospheric $\mathrm{N}$ input to the terrestrial biosphere has increased as a result of fossil fuel burning and from fertilizer application [Nadelhoffer et al., 1999; Holland et al., 2005]. A large increase in atmospheric $\mathrm{N}$ input to regions that are typically $\mathrm{N}$ limited, such as northern temperate forests, could increase $\mathrm{C}$ accumulation in these regions [Vitousek and Howarth, 1991; Hyvönen et al., 2007]. Several studies [Holland et al., 1997; Nadelhoffer et al., 1999; Churkina et al., 2007; Thornton et al., 2007] have concluded that $\mathrm{N}$ deposition enhances terrestrial carbon storage across the globe.

[7] Human activities have significantly altered the Earth's vegetation cover in nearly every part of the world. Such changes have the potential to alter regional and global climate through changes in the biophysical characteristics of the Earth's surface, such as albedo and surface roughness [Ramankutty and Foley, 1999; Brovkin et al., 2006], and in the biogeochemical cycles of terrestrial ecosystems, such as the global $\mathrm{C}$ and $\mathrm{N}$ cycles. Historically, land use change has generally released carbon to the atmosphere due to the conversion of forests to croplands and pastures, but in recent decades. C stocks in forest ecosystems have also increased through reforestation, afforestation and forest regrowth on abandoned land [Jain and Yang, 2005]. How- ever, the accumulation of $\mathrm{C}$ stocks can be constrained if the land use changes occur in $\mathrm{N}$ limited regions [Davidson et al., 2004].

[8] While most previous modeling studies have investigated how the $\mathrm{N}$ cycle influences the responses of the terrestrial $\mathrm{C}$ cycle to individual environmental factors, here we take the next step to evaluate how the $\mathrm{N}$ cycle has influenced the 20th century terrestrial $\mathrm{C}$ cycle responses to the combination of increased $\left[\mathrm{CO}_{2}\right]$, changes in climate (temperature and precipitation), and $\mathrm{N}$ deposition in addition to land cover and land use change (LCLUC). We conduct this evaluation with the Integrated Science Assessment Model (ISAM), a geographically explicit terrestrial ecosystem model with fully coupled $\mathrm{C}$ and $\mathrm{N}$ cycles. Specifically, the impacts of sufficient and limited $\mathrm{N}$ supply on $\mathrm{C}$ pools and fluxes for each of the prescribed environmental changes alone and in combination are evaluated.

\section{Methods}

[9] We performed several experiments, as discussed below, using the extended version of the process-based global terrestrial $\mathrm{C}$ and $\mathrm{N}$ cycle component of the ISAM (Figure 1). The structure, parameterization, and performance of the ISAM have been previously discussed [Jain and Yang, 2005; Yang et al., 2009]; here we provide a brief description of the model.

[10] ISAM simulates $\mathrm{C}$ and $\mathrm{N}$ fluxes within the terrestrial biosphere at a $0.5^{\circ} \times 0.5^{\circ}$ spatial resolution. Each grid cell is occupied by one of 105 soil types from the FAOUNESCO Soil Map of the World [Zobler, 1999], and at least one of 13 natural land cover classifications based on vegetation data sets from Loveland and Belward [1997] and Haxeltine and Prentice [1996].

[11] The $\mathrm{C}$ and $\mathrm{N}$ are cycled among the vegetation (tree and aboveground foliage and tree-woody biomass), aboveground litter (dead foliage and dead wood), belowground litter (dead roots), aboveground and belowground soil organic matter (SOM) (microbial biomass and humus), and inorganic $\mathrm{N}\left(\mathrm{NH}_{4}^{+}\right.$and $\left.\mathrm{NO}_{3}^{-}\right)$pools. The $\mathrm{C}$ dynamics of vegetation pools are based on the work of Jain and Yang [2005], whereas $\mathrm{N}$ content in each vegetation pool and biome is calculated based on $\mathrm{C}: \mathrm{N}$ ratios as defined by Yang et al. [2009]. Net primary production $\left(\mathrm{kg} \mathrm{C} \mathrm{m}^{-2} \mathrm{yr}^{-1}\right)$ for the tree and aboveground foliage and tree-woody biomass pools varies with vegetation $\mathrm{C}$ according to empirical plant growth equations [Jain et al., 1996; Kheshgi et al., 1996; King et al., 1995]. The photosynthetically active vegetation carbon reservoirs are characterized by their turnover times and the rate of exchange between them. The values of these parameters for each of our model's land cover types are calculated from the specified initial values of fraction of tree and ground vegetation carbon $\left(\mathrm{kgC} \mathrm{m}^{-2} \mathrm{yr}^{-1}\right)$ as describe in detailed by Jain and Yang [2005]. The modeled NPP is consistent with other studies [Prentice et al., 2001; Cramer et al., 1999] as noted by Jain and Yang [2005]. The C dynamics for aboveground litter and SOM pools are calculated based on equations derived from Parton et al. [1987], Parton and Rasmussen [1994], and Moorhead et al. [1999], whereas the belowground litter (dead roots) and SOM 


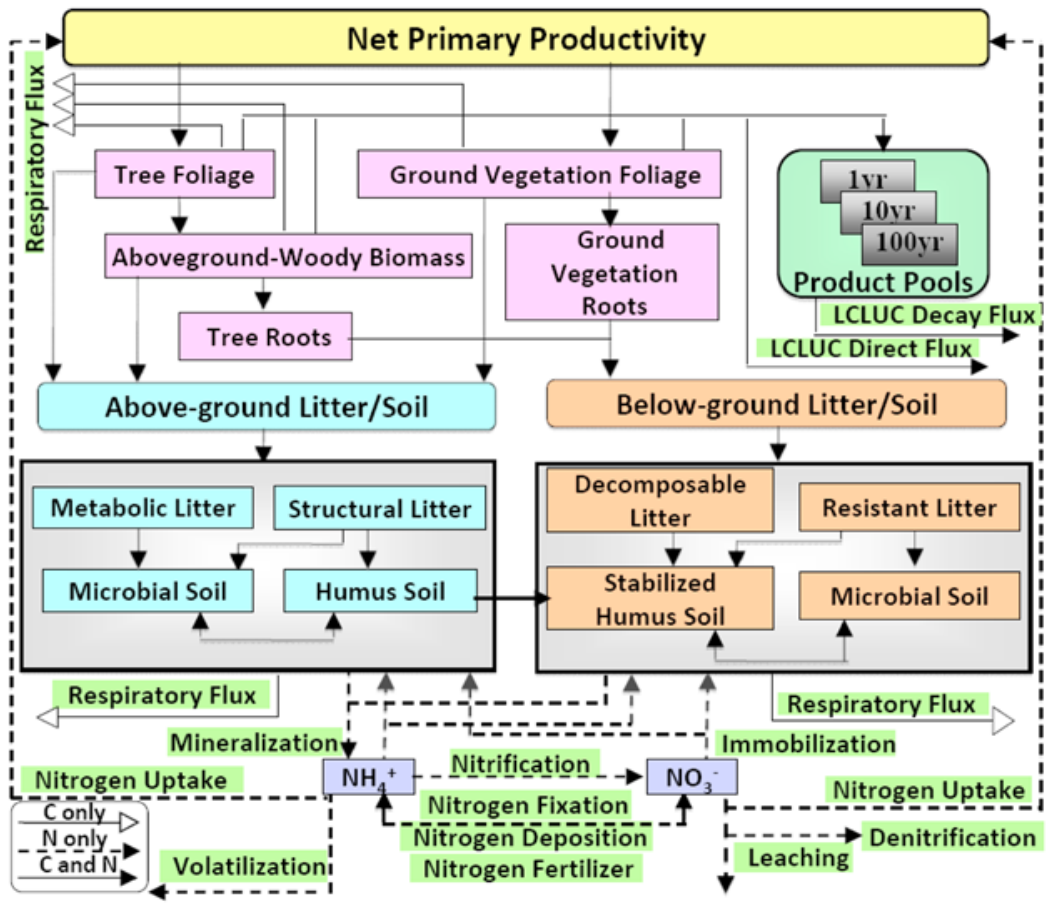

Figure 1. Schematic diagram of all reservoirs and flows in the ISAM coupled carbon-nitrogen cycle model.

dynamics are estimated based on the RothC model equations [Jenkinson, 1990; Coleman and Jenkinson, 1999; Paul and Polglase, 2004; Jain and Yang, 2005]. The change in $\mathrm{N}$ contents of aboveground and belowground litter and SOM pools follow the changes in $\mathrm{C}$ contents and are equal to the product of the changes in $\mathrm{C}$ and $\mathrm{C}: \mathrm{N}$ ratio as discussed by Yang et al. [2009].

[12] There are three sources of $\mathrm{N}$ inputs: the deposition of atmospheric $\mathrm{N}$ species ( $\mathrm{N}$ deposition), biological $\mathrm{N}$ fixation and $\mathrm{N}$ fertilizers (as nitrate, ammonium, or both). $\mathrm{N}$ fertilizers input are not considered in this study. Table 1 provides the external $\mathrm{N}$ input and output for the initial and last year of model simulations. There are four $\mathrm{N}$ output flux pathways: denitrified $\mathrm{N}$, leached $\mathrm{N}$, volatilized $\mathrm{N}$ and LCLUC $\mathrm{N}$ removals. The $\mathrm{N}$ volatilization flux is minimal in unfertilized systems and ignored in our study. In the model C and $\mathrm{N}$ in vegetation and soil are linked through litter fall, decomposition, $\mathrm{N}$ mineralization and microbial immobilization, and $\mathrm{N}$ uptake by vegetation. Three types of litter are considered in this study: leaf litter, wood litter and root litter. The production and distribution of organic matter into various litter $\mathrm{C}$ pools are based on $\mathrm{C}$, lignin and $\mathrm{N}$ concentrations, and climate conditions as described by Yang et al. [2009]. During the decomposition of aboveground and belowground litter and $\mathrm{SOM}$, part of $\mathrm{C}$ is respired and the rest is exchanged between litter and SOM pools as shown in Figure 1. Both immobilization and mineralization of $\mathrm{N}$ can occur during decomposition depending on the $\mathrm{C}: \mathrm{N}$ ratio of the litter and SOM pools and the microbial efficiency [Yang et al., 2009]. If the transferred amount of $\mathrm{C}$ from one pool to the other requires less $\mathrm{N}$ to maintain the specified $\mathrm{C}: \mathrm{N}$ ratio of humus and microbial pool, $\mathrm{N}$ is added to mineralized $\mathrm{N}$ pools. In contrast, if the transferred amount of $\mathrm{C}$ requires additional $\mathrm{N}$ to maintain the specified $\mathrm{C}: \mathrm{N}$ ratio, immobilization of inorganic $\mathrm{N}$ from both soil mineral reservoirs, i.e., ammonium $\left(\mathrm{NH}_{4}^{+}\right)$and nitrate $\left(\mathrm{NO}_{3}^{-}\right)$, occurs [Yang et al., 2009]. In the model, $\mathrm{NH}_{4}^{+} \mathrm{N}$ is nitrified to nitrate $\mathrm{NO}_{3}^{-} \mathrm{N}$ according to Bradbury et al. [1993]. $\mathrm{NH}_{4}^{+} \mathrm{N}$ is immobilized in preference to $\mathrm{NO}_{3}^{-}$, and nitrification occurs before denitrification. Plant $\mathrm{N}$ uptake depends on plant-available mineral N, temperature, soil moisture, and root mass and is estimated by using Michaelis-Menten kinetics [Raich et al., 1991]. When the calculated $\mathrm{N}$ demand is greater than $\mathrm{N}$ supply, NPP is scaled back to the level that N supply can support [McGuire et al., 1992]. For example, under conditions of $\mathrm{N}$ limitation, photosynthesis is down regulated, therefore reducing NPP. On the other hand, if N demand is less than supply, plant production and NPP are enhanced until NPP is limited by other factors, such as soil moisture.

[13] At each time step the available nitrogen pool is incremented with nitrogen inputs from mineralization, fixation, and deposition. Then NPP is up- or down-regulated using this amount. After the amount required for plant growth is removed, the losses of remaining $\mathrm{NO}_{3}^{-}-\mathrm{N}$ to leaching are calculated and the available $\mathrm{N}$ pool decremented.. The $\mathrm{NO}_{3}^{-}-\mathrm{N}$ leaching is determined by the soil $\mathrm{NO}_{3}^{-}-\mathrm{N}$ pool, field capacity of the soil, and percolation according to Yang et al. [2009]. The soil water budget model by Pastor and Post [1985] as implemented by Jain and Yang [2005] is used to calculate soil water content and percolation. $\mathrm{NH}_{4}^{+} \mathrm{N}$ can be lost by volatilization after the application of $\mathrm{NH}_{4}^{+}$fertilizers and is modeled using the formulations of Bradbury et al. [1993]. The biological N fixation for each biome type is estimated using the empirical 
Table 1. External N Inputs and Outputs for the Initial (1765) and Last Year (2000) of Model Simulations ${ }^{a}$

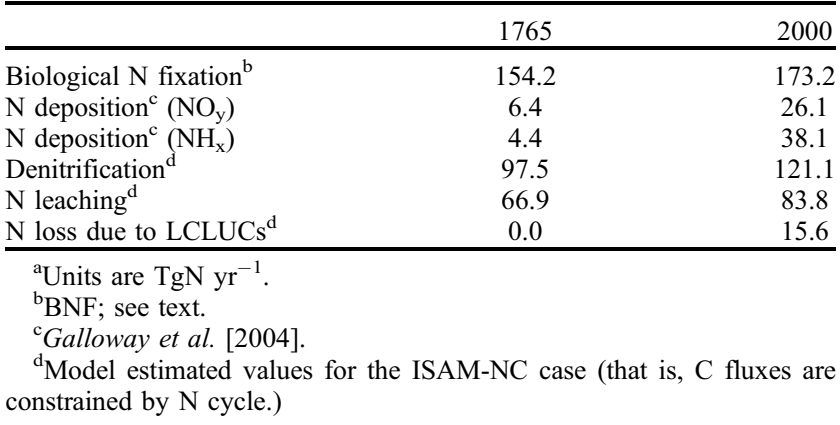

functions developed based on the relationship between evapotranspiration and $\mathrm{N}$ fixation [Schimel et al., 1996; Cleveland et al., 1999]. Another input for inorganic $\mathrm{N}$ in soil is atmospheric wet and dry deposition. In this study, we use historical deposition data provided by Galloway et al. [2004].

[14] ISAM also considers how $\mathrm{C}$ and $\mathrm{N}$ dynamics are influenced by land cover and land use change (LCLUC) activities, i.e., deforestation, reforestation and afforestation [Yang et al., 2009]. With removal of natural vegetation in an affected grid cell, a specified fraction of vegetation biomass is transferred to litter reservoirs as slash left on the ground. The $\mathrm{C}$ and $\mathrm{N}$ in these reservoirs are subject to decomposition as discussed above and by Yang et al. [2009]. The rest of plant material is either burned to clear the land for agriculture, which releases $\mathrm{C}$ and $\mathrm{N}$ contained in the burned plant material (see LCLUC Direct Flux in Figure 1), or is transferred as $\mathrm{C}$ and $\mathrm{N}$ to wood and/or fuel product reservoirs (see Product Pools in Figure 1). Carbon and $\mathrm{N}$ stored in the product pools are released to the atmosphere (see LCLUC Decay Flux in Figure 1) at a variety of rates dependent on usage and assigned products into three general reservoirs with turnover times of 1 year (agriculture and agriculture products), 10 years (paper and paper products) and 100 years (lumber and long-lived products) [Jain and Yang, 2005].

[15] Because litter decomposition provides the primary source of energy and $\mathrm{N}$ for soil microorganisms, we have, in a separate study [Yang et al., 2009], evaluated the litter decomposition components of the ISAM framework with the Long-Term Intersite Decomposition Experiment (LIDET) data set, which consist of a range of observed litter input rates, types, and climate conditions [LIDET, 1995; Parton et al., 2007]. This site-specific analysis demonstrates that ISAM is able to adequately capture C and $\mathrm{N}$ dynamics during decomposition. At the global scale, the spatial distribution of vegetation and soil $\mathrm{N}, \mathrm{N}$ uptake and $\mathrm{N}$ leaching are consistent with previous measurement and model studies as discussed below. This gives us confidence that the ISAM framework used in this study can predict plant $\mathrm{N}$ availability and subsequent plant productivity at regional and global scales and how they can be impacted by factors that alter the rate of decomposition such as increasing $\left[\mathrm{CO}_{2}\right]$, climate changes, litter quality, soil microbial activity and/or increased input of $\mathrm{N}$ to the system via $\mathrm{N}$ deposition.

\section{Model Simulations}

[16] The ISAM is initialized with an $\left[\mathrm{CO}_{2}\right]$ of $278 \mathrm{ppmv}$, representative of approximate conditions in 1765, and constant monthly mean temperature and precipitation for the period 1900-1920 [Mitchell and Jones, 2005] to allow vegetation and soil $\mathrm{C}$ and mineral $\mathrm{N}$ pools to reach an initial dynamic steady state [Yang et al., 2009]. Once the model reaches dynamic steady state, the historical changes in net $\mathrm{C}$ uptake between 1765 and 2000 are calculated for two N cycle scenarios: (1) simulations with a fully dynamic $\mathrm{N}$ cycle (ISAM-NC) where $\mathrm{N}$ is allowed to vary according to $\mathrm{C}$ and $\mathrm{N}$ cycle dynamics and (2) simulations in which $\mathrm{N}$ is always sufficiently available for plant growth; that is, $\mathrm{C}$ fluxes are not constrained by $\mathrm{N}$ cycle (ISAM-C). We run these two $\mathrm{N}$ cycle scenarios of the ISAM with independent changes in (1) increasing $\left[\mathrm{CO}_{2}\right]$ [Keeling and Whorf, 2007], (2) observed temperature and precipitation [Mitchell and Jones, 2005], (3) N deposition [Galloway et al., 2004], and (4) land cover changes involving croplands [Jain and Yang, 2005]; and combined changes in (1)-(4).

[17] In the increasing $\left[\mathrm{CO}_{2}\right]$ case, we used annual averaged $\left[\mathrm{CO}_{2}\right]$ which have risen from a preindustrial level of about 278 ppmv in 1765 to 370 ppmv in 2000 [Keeling and Whorf, 2007]. In the climate change case, the global average surface temperature has increased by $0.6 \pm 0.2^{\circ} \mathrm{C}$ over the period 1901-2000. The largest increases in temperature since 1975 have occurred over the middle and high latitudes of the continents in the Northern Hemisphere. Precipitation data is highly variable temporally and spatially. The data for historical changes in LCLUCs for cropland area for the period 1765-1992 are based on the work of Ramankutty and Foley [1998, 1999]. For the period between 1992 and 2000, we linearly extrapolated cropland area within each grid cell based on land use trends in the previous decade. Changes in $\mathrm{N}$ deposition $\left(\mathrm{NO}_{\mathrm{y}}+\mathrm{NH}_{\mathrm{x}}\right)$ are based on the work of Galloway et al. [2004], which accounts for both direct wet and dry depositions and are calculated on a $5^{\circ} \times$ $3.75^{\circ}$ grid using a global transport chemistry model [Lelieveld and Dentener, 2000]. Each grid data was then subdivided into a $0.5 \times 0.5$ subgrid scale. Over the time period 1860-2000, the global total net exchange of $\mathrm{N}$ deposition flux from the atmosphere to land increases from $10.81\left(\mathrm{NO}_{\mathrm{y}}=6.45, \mathrm{NH}_{\mathrm{x}}=4.35\right)$ to $62.29\left(\mathrm{NO}_{\mathrm{y}}=\right.$ 26.1, $\left.\mathrm{NH}_{\mathrm{x}}=36.1\right) \mathrm{TgN} \mathrm{yr}^{-1}$ (Table 1). For the period $1765-1859$, we assume the same value as for the 1860 . Over the period 1765-2000, the model estimated global total biological $\mathrm{N}$ fixation (BNF) increases from 153 to $174 \mathrm{TgN} \mathrm{yr}^{-1}$ (Table 1). Although the uncertainties in global estimated BNF flux using different methods are quite large, Cleveland et al. [1999] and Galloway et al. [2004] suggest that annual global BNF contributed between 100 and $290 \mathrm{TgN} \mathrm{yr}^{-1}$ to natural terrestrial ecosystems and our estimated values for the period $1765-2000$ are well within the range of these values.

[18] In section 4, three sets of the ISAM estimated results are presented: (1) global annual-mean net $\mathrm{C}$ fluxes and 

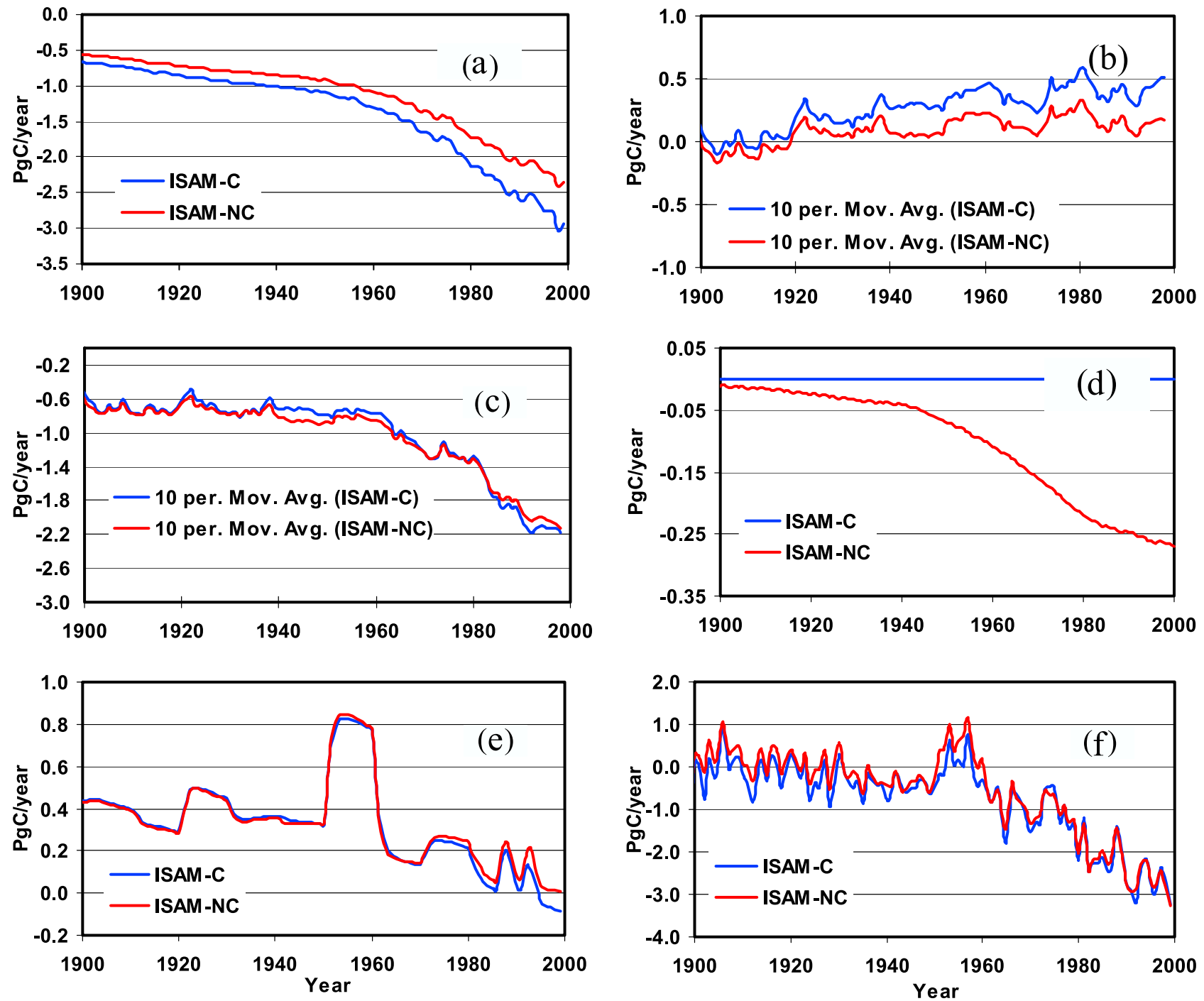

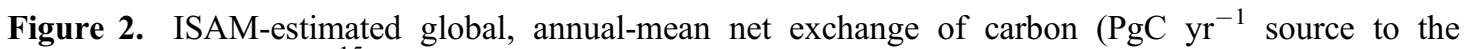
atmosphere; $1 \mathrm{Pg}=10^{15} \mathrm{~g}$ ) for cases ISAM-NC (C fluxes are constrained by $\mathrm{N}$ cycle) and ISAM-C (C fluxes are not constrained by $\mathrm{N}$ cycle) between 1900 and 2000 as a result of changes in (a) concentrations of atmospheric $\mathrm{CO}_{2}$, (b) climate (temperature and precipitation), (c) $\mathrm{CO}_{2}$ and climate, (d) nitrogen deposition, (e) LCLUCs, and (f) all drivers: $\mathrm{CO}_{2}$, climate, nitrogen deposition, and LCLUCs. Positive values indicate net emission to the atmosphere and negative values indicate a net sink by the terrestrial biosphere. The term 10per.Mov.Avg in Figures $2 \mathrm{~b}$ and $2 \mathrm{c}$ stands for 10 year moving average.

changes in vegetation and soil organic $\mathrm{C}$ and/or $\mathrm{N}$ for ISAM-NC and ISAM-C over the period 1900-2000, (2) the difference of spatial distributions and temporal trends in net $\mathrm{C}$ flux for the with- and without-N dynamics cases (ISAM-NC minus ISAM-C) for 1990 to 2000 time period, and (3) the comparison of the latitudinal distribution of biome-specific mean annual net $\mathrm{C}$ fluxes for ISAM-NC and ISAM-C cases for the 1990s.

\section{Results}

[19] Increasing $\left[\mathrm{CO}_{2}\right]$ drives terrestrial ecosystems to act as a sink for $\left[\mathrm{CO}_{2}\right]$ due to the $\mathrm{CO}_{2}$ fertilization effect for both cases ISAM-NC and ISAM-C. The $\mathrm{C}$ uptake rates, however, are lower for case ISAM-NC than for case ISAM-C between 1900 and 2000 as shown in Figure 2a. For increasing $\mathrm{CO}_{2}$, available $\mathrm{N}$ in the ISAM-NC calculations is drawn down as the supply of $\mathrm{N}$ to plants cannot meet the demand of $\mathrm{N}$ by plants for new production and photosynthesis is "down-regulated." The soil C is also lower in ISAM-NC than in case ISAM-C (Figure 3a), with lower NPP, biomass in vegetation and litterfall to support the changes in soil $\mathrm{C}$. The difference in $\mathrm{C}$ uptake by the terrestrial ecosystems between the ISAM-NC and the ISAM-C simulations due to rising $\left[\mathrm{CO}_{2}\right]$ becomes progressively greater through the 20th century (Figure 2a).

[20] Rising $\left[\mathrm{CO}_{2}\right]$ enriches the organic matter in plants with $\mathrm{C}$, which leads to an increase in $\mathrm{C}: \mathrm{N}$ ratios of 

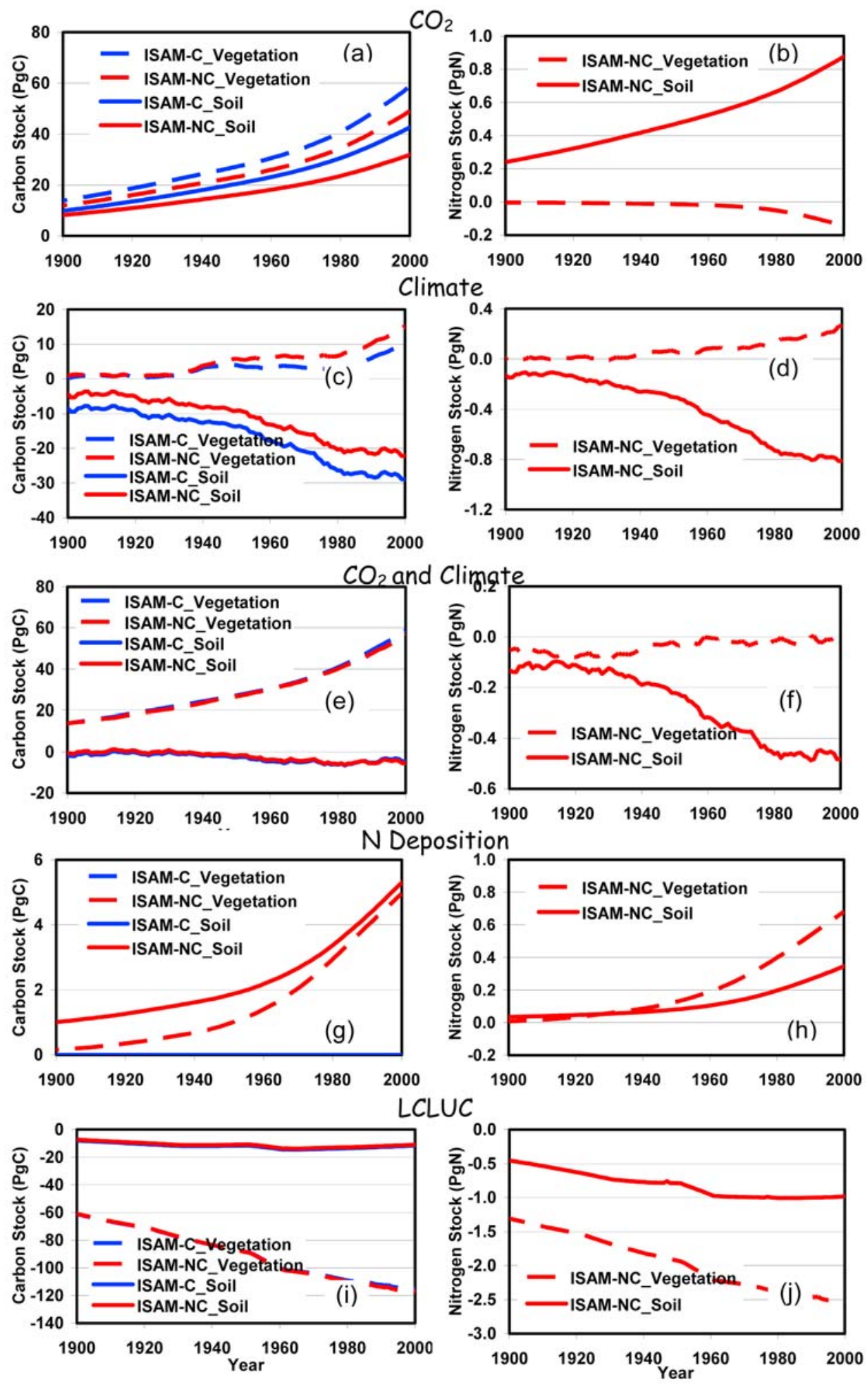

Figure 3. (a, c, e, g, i) ISAM model estimated vegetation and soil organic carbon stocks for ISAM-C and $(b, d, f, h, j)$ vegetation and soil organic nitrogen stocks for ISAM-NC case. Modeled $\mathrm{C}$ and $\mathrm{N}$ stocks driven by changes in $\mathrm{CO}_{2}$ (Figures $3 \mathrm{a}$ and $3 \mathrm{~b}$ ), climate (Figures $3 \mathrm{c}$ and $3 \mathrm{~d}$ ), $\mathrm{CO}_{2}$ and climate (Figures $3 \mathrm{e}$ and $3 \mathrm{f}$ ), $\mathrm{N}$ deposition (Figures $3 \mathrm{~g}$ and $3 \mathrm{~h}$ ), and land cover and land use changes (LCLUCs) (Figures $3 \mathrm{i}$ and $3 \mathrm{j})$ are shown as their difference from their 1765 values: 864 and $1806 \operatorname{PgC}\left(1 \mathrm{Pg}=10^{15} \mathrm{~g}\right)$ and 18 and $75 \mathrm{GtN}$ in vegetation and soils, respectively. 

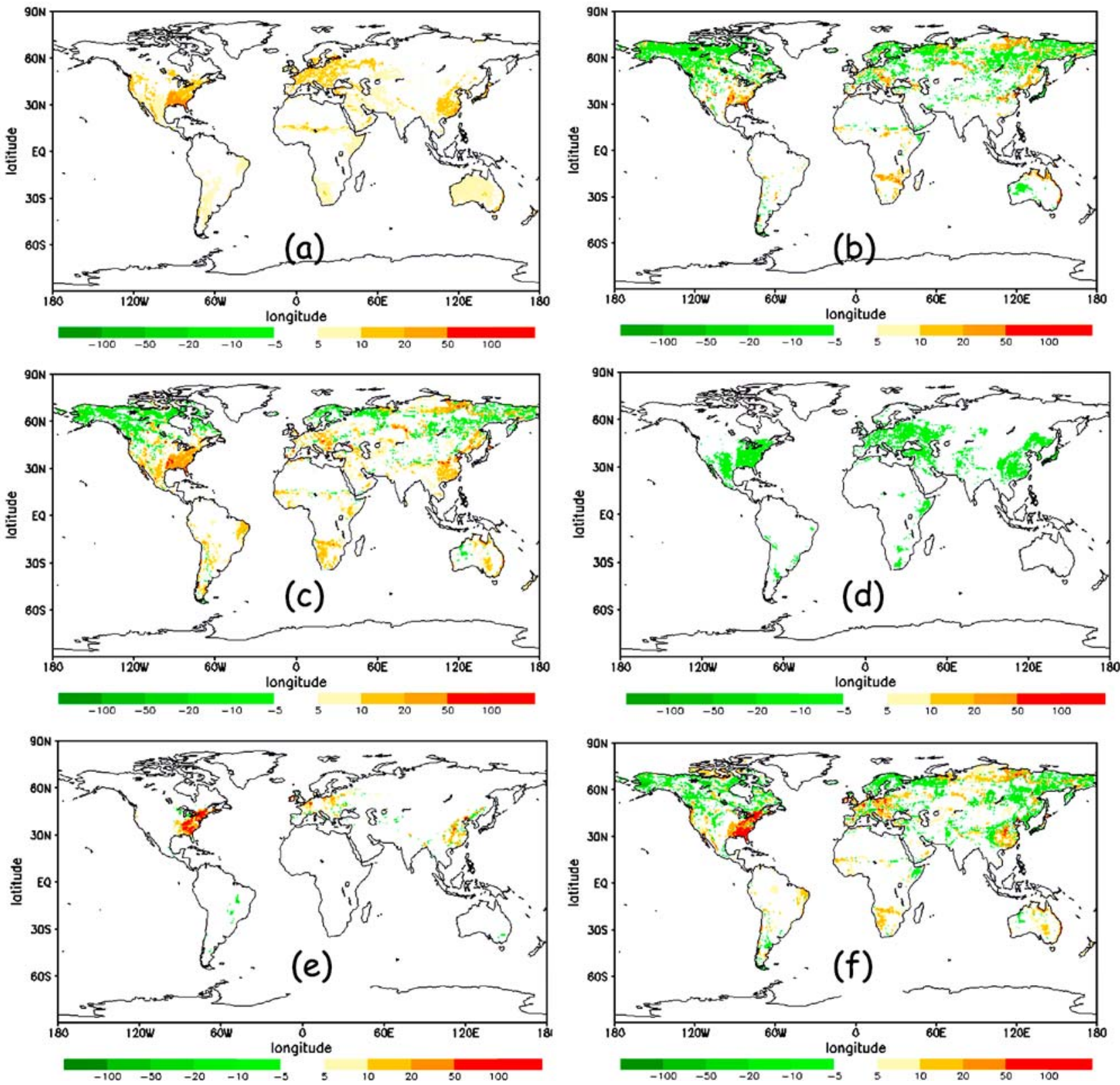

Figure 4. Spatial distributions are shown of the difference in modeled carbon flux to the atmosphere $\left(\mathrm{gC} \mathrm{m}^{2} \mathrm{yr}^{-1}\right.$ ) between the with- and without-N dynamics cases (ISAM-NC minus ISAM-C) during the 1990 s driven by changes in (a) concentrations of atmospheric $\mathrm{CO}_{2}$, (b) climate (temperature and precipitation), (c) $\mathrm{CO}_{2}$ and climate, (d) nitrogen deposition, (e) LCLUCs, and (f) $\mathrm{CO}_{2}$, climate, nitrogen deposition, and LCLUCs. The modeled change in carbon storage, due to the addition of nitrogen dynamics, leads to additional carbon storage in the terrestrial biosphere where values are negative and reduced storage where values are positive.

vegetation pools in ISAM-NC by about $7 \%$ over the time period 1765-2000. However, litter generated from the $\mathrm{C}$-rich plant biomass also has high $\mathrm{C}: \mathrm{N}$ ratio, which decreases the rate of decomposition per gram of litter and increases the immobilization of $\mathrm{N}$ by soil organisms. This additional demand of the mineral $\mathrm{N}$ by soil organisms amplifies the $\mathrm{N}$ limitation of vegetation, which further increase the $\mathrm{C}: \mathrm{N}$ ratios of vegetation and leads to a transfer of $\mathrm{N}$ from vegetation pools to soil pools (Figures $3 \mathrm{~b}$ ).
Terrestrial $\mathrm{C}$ storage also decreases in case ISAM-NC as compared to ISAM-C case (Figure 3a). Our model results, which are consistent with the Sokolov et al. [2008] analysis, show that modeled improvements in plant $\mathrm{N}$ use efficiency with elevated levels of $\mathrm{CO}_{2}$ allow vegetation to continue to sequester $\mathrm{C}$ (Figure 3a). The ISAM-NC model estimated results show that the amount of plant $\mathrm{N}$ remains constant or decreases with increasing $\left[\mathrm{CO}_{2}\right]$ (Figure 3b). 


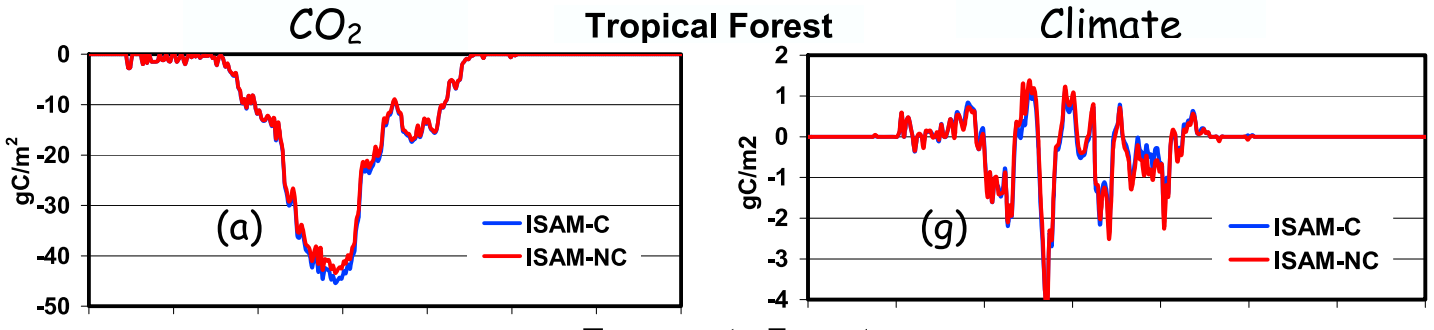

Temperate Forest
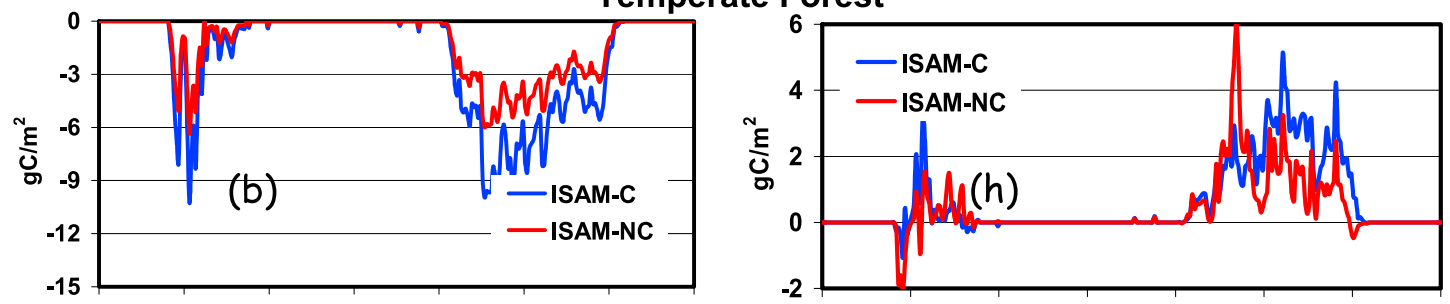

Boreal Forest
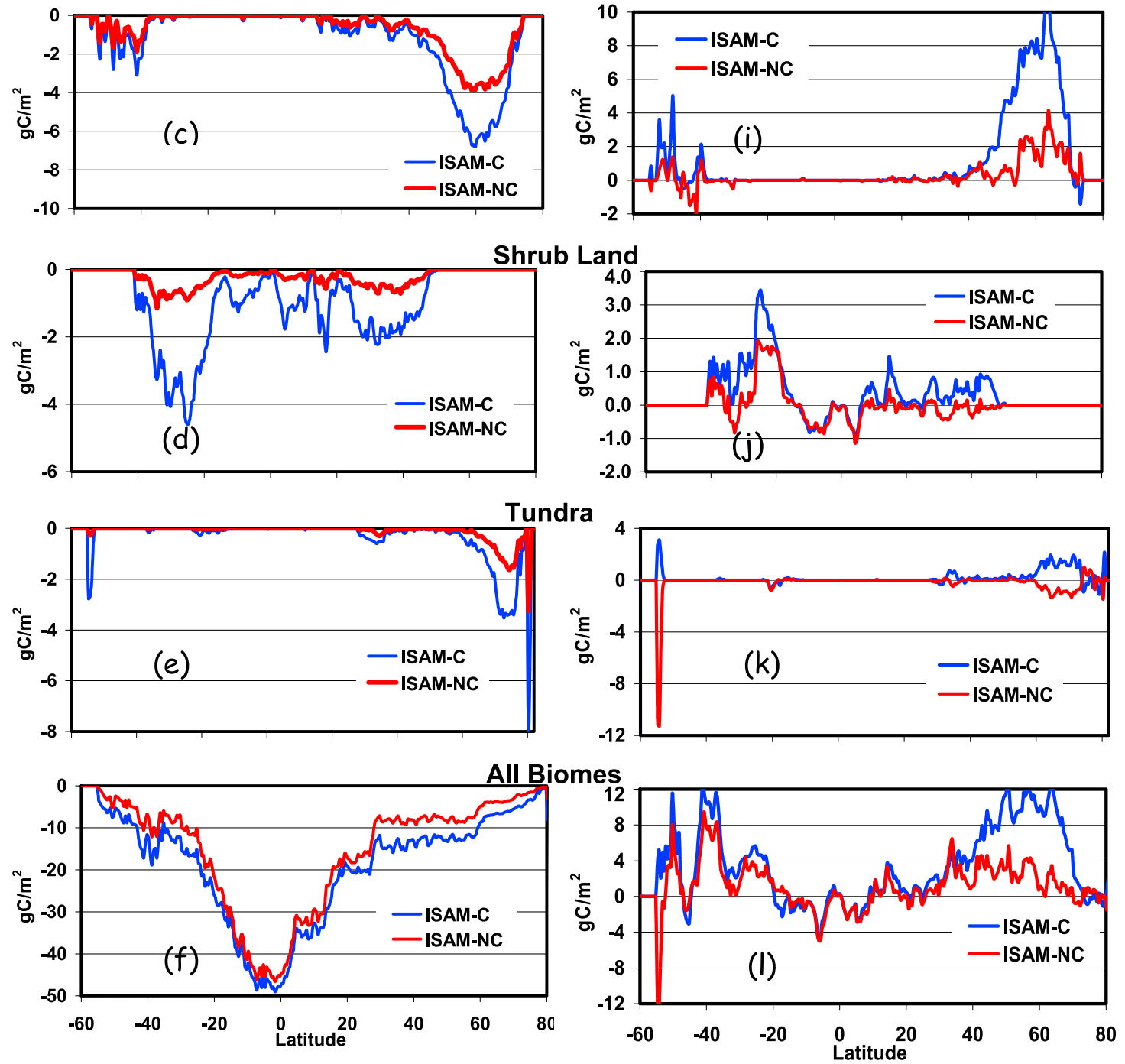

Figure 5. ISAM-estimated global and annual-mean latitudinal distribution of net carbon flux of carbon (gC m $\mathrm{yr}^{-1}$ ) for the 1990s as a result of changes in concentrations of (left) atmospheric $\mathrm{CO}_{2}$ and (right) climate (temperature and precipitation) for different individual biomes and all biomes. The results are compared for cases where $\mathrm{C}$ fluxes are constrained by $\mathrm{N}$ cycle (ISAM-NC) and $\mathrm{C}$ fluxes are not constrained by $\mathrm{N}$ cycle (ISAM-C). 


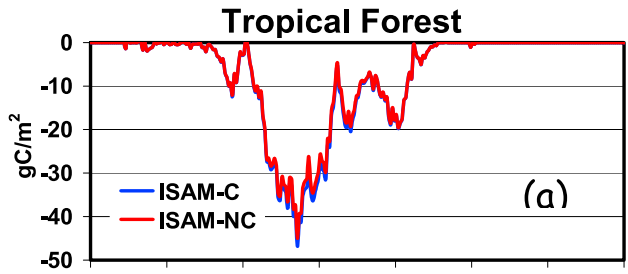

Temperate Forest
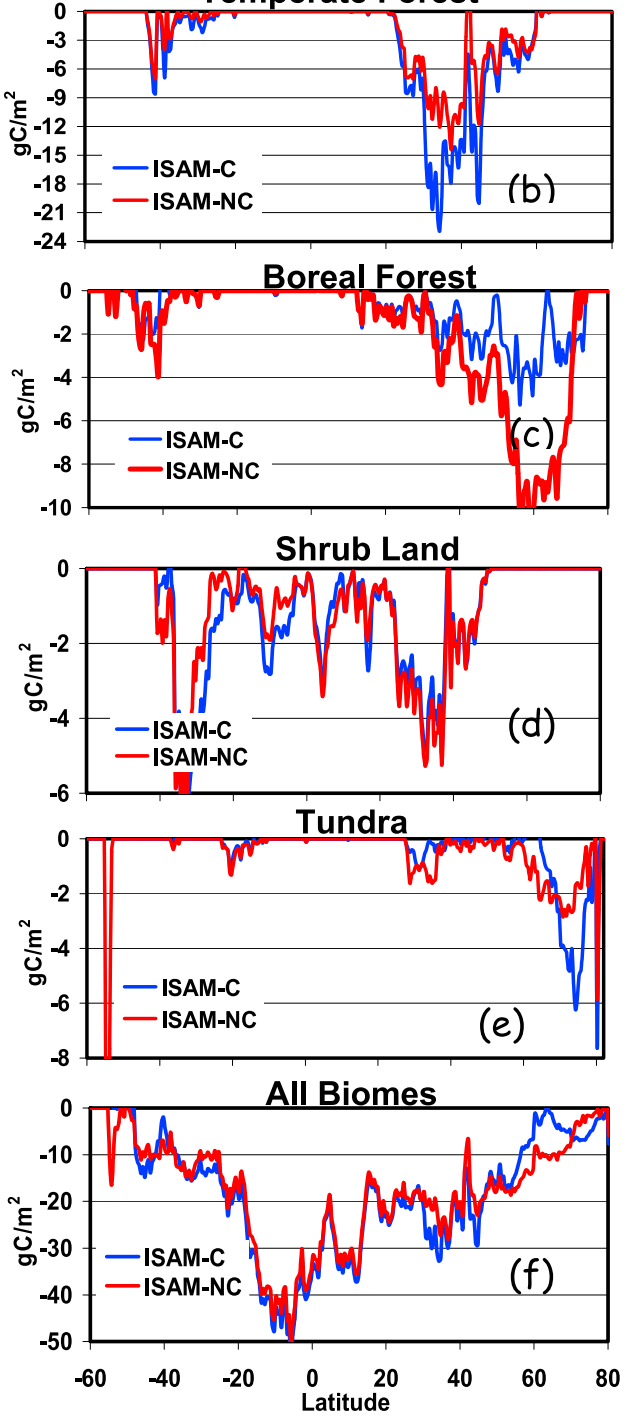

Figure 6. ISAM-estimated global and annual-mean latitudinal distribution of net carbon flux of carbon $\left(\mathrm{gC} \mathrm{m}^{2} \mathrm{yr}^{-1}\right)$ for the $1990 \mathrm{~s}$ as a result of combined changes in atmospheric $\mathrm{CO}_{2}$, climate (temperature and precipitation), $\mathrm{N}$ deposition, and LCLUCs for different individual biomes and for all biomes. The results are compared for cases where $\mathrm{C}$ fluxes are constrained by $\mathrm{N}$ cycle (ISAM-NC) and $\mathrm{C}$ fluxes are not constrained by $\mathrm{N}$ cycle (ISAM-C).

[21] Our model results also demonstrate that the impact of $\mathrm{N}$ limitation (ISAM-NC minus ISAM-C) (Figure 4a) on terrestrial net $\mathrm{C}$ flux during the 1990s is spatially heterogeneous across the globe. In general, the inclusion of $\mathrm{N}$ dynamics significantly reduces the $\mathrm{CO}_{2}$ fertilization response relative to the case where $\mathrm{N}$ is sufficiently available for plants to grow (Figure 4a). Nitrogen limitation is clearly indicated in moist temperate regions (i.e., less $\mathrm{C}$ uptake in ISAM-NC compared to ISAM-C, Figure 5b), where $\mathrm{N}$ is a primary limiting nutrient. While high-latitude boreal forests and tundra regions are also limited in $\mathrm{N}$ availability (Figures $5 \mathrm{c}$ and $5 \mathrm{e}$ ), the response of these regions to $\mathrm{N}$ limitation is less pronounced than the temperate evergreen deciduous and evergreen forest regions (Figure 4a) because ecosystem productivity in high latitudes is limited by shorter growing seasons and relatively less $\mathrm{N}$ is required for plant growth. While tropical regions are highly productive, they are not $\mathrm{N}$ limited (Figures 4a, 5a, and 6a). Our results indicate that $\mathrm{N}$ does not limit productivity in tropical forests. These results are consistent with studies that suggest that phosphorus limits NPP in tropical forests [Harrington et al., 2001]. Our results are also consistent with studies that have documented $\mathrm{N}$ limitation of productivity in tropical shrub lands (Figure 5d) [Yates et al., 1982; Gallardo and Schlesinger, 1992].

[22] For the 1990s, the ISAM-NC estimates the global mean terrestrial sink associated with increasing $\left[\mathrm{CO}_{2}\right]$ to be $0.53 \mathrm{PgC} \mathrm{yr}^{-1}$ less than that estimated by ISAM-C (Table 2). This suggests that ISAM-C overestimates the $\mathrm{CO}_{2}$ fertilization effect during 1990 s by about $24 \%$ due to $\mathrm{N}$ limitation. These results are directionally consistent with previous modeling studies that have reported that the response of terrestrial ecosystems to increasing $\left[\mathrm{CO}_{2}\right]$ can be substantially limited by $\mathrm{N}$ availability [McGuire et al., 1997, 2001; Kicklighter et al., 1999; Thornton et al., 2007].

[23] In addition to $\left[\mathrm{CO}_{2}\right]$, the results of both versions of the ISAM indicate that terrestrial carbon storage is sensitive to climate variability and changes over the time period 1900-2000 (Figure 2b). For both ISAM-NC and ISAM-C, interannual variability in temperature and precipitation induces interannual variations in net $\mathrm{C}$ fluxes that are of a rate on order of almost $2.5 \mathrm{PgC} \mathrm{yr}^{-1}$ (results not shown here). Net release of $\mathrm{CO}_{2}$ to the atmosphere from 1900 to 2000 for both cases results from an increase in decomposition due to higher temperature. However, $\mathrm{C}$ release to the atmosphere is smaller for ISAM-NC than for ISAM-C. Although mean changes in temperature and precipitation lead to increased decomposition in both cases, increased $\mathrm{N}$ mineralization associated with enhanced microbial decomposition in ISAM-NC increases plant-available mineral $\mathrm{N}$ in soil and stimulates plant $\mathrm{N}$ uptake, productivity, and the $\mathrm{C}$ uptake by plants (Figure 3c). Our modeling results, which are close to changes simulated by TEM model [Sokolov et al., 2008] but somewhat lower than changes produced by Thornton et al. [2007], suggest that in ISAM-NC the amount of $\mathrm{C}$ loss to the atmosphere as a result of the temperature-driven enhancements in autotrophic and heterotrophic respiration is partially compensated by a climate-enhanced productivity of plants. The increase in mineralization in the ISAM-NC also redistributes $\mathrm{N}$ between soils and vegetation, i.e., the loss of $\mathrm{N}$ from soils, and increases $\mathrm{N}$ in vegetation (Figure 3d). Overall, the higher plant growth in ISAM-NC also increases the amount of litterfall and $\mathrm{C}$ in soils. Therefore, the loss of soil $\mathrm{C}$ in 
Table 2. Comparisons of the ISAM Model Estimated Effect of Single Environmental Factors as Well as Combined Factors ${ }^{\mathrm{a}}$

\begin{tabular}{lccc}
\hline \multicolumn{1}{c}{ Driver } & $\begin{array}{c}\text { Case } \\
\text { ISAM-C }\end{array}$ & $\begin{array}{c}\text { Case } \\
\text { ISAM-NC }\end{array}$ & $\begin{array}{c}\text { ISAM-NC Minus } \\
\text { ISAM-C }\end{array}$ \\
\hline Atmospheric $\mathrm{CO}_{2}$ & -2.72 & -2.19 & 0.53 \\
Climate & 0.51 & 0.17 & -0.34 \\
Atmospheric $\mathrm{CO}_{2}$ & -2.13 & -2.08 & 0.05 \\
$\quad$ and climate & & & \\
$\quad \mathrm{N}$ deposition & 0.00 & -0.26 & -0.26 \\
Land use & 0.002 & 0.08 & 0.08 \\
Total & -2.48 & -2.57 & -0.09 \\
$\quad$ & & $-1 \pm 0.6$ & \\
Net terrestrial uptake & & & \\
$\quad$ Denman et al., 2007] & & & \\
\hline
\end{tabular}

${ }^{\mathrm{a}}$ The cases considered here are ISAM-NC ( $\mathrm{C}$ fluxes are constrained by $\mathrm{N}$ cycle) and ISAM-C (C fluxes are not constrained by $\mathrm{N}$ cycle). The model results are also compared with the IPCC estimated net terrestrial carbon uptake [Denman et al., 2007]. Positive values indicate net emission to the atmosphere and negative values indicate net sink in the terrestrial biosphere at a global annual rate $\left(\mathrm{PgC} \mathrm{yr}^{-1}, 1 \mathrm{Pg}=10^{15} \mathrm{~g}\right)$ averaged over the $1990 \mathrm{~s}$.

ISAM-NC is less than in ISAM-C (Figure 3c). These results are directionally consistent with previous global modeling studies [Thornton et al., 2007; Sokolov et al., 2008].

[24] At the global scale, the model results for the 1990s show that the additional mineral $\mathrm{N}$ available for terrestrial ecosystems under warming conditions leads to an indirect $\mathrm{N}$ fertilization effect and reduces the $\mathrm{C}$ loss to the atmosphere

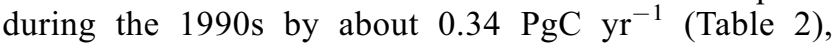
although again the results are spatially heterogeneous depending on region and biomes. Overall, high-latitude regions show a marked decrease of $\mathrm{C}$ emission from terrestrial ecosystems in ISAM-NC case relative to ISAM-C case (Figure 51), particularly boreal forest (Figure 5i), shrub lands (south of $30^{\circ} \mathrm{S}$ ) (Figure 5j) and tundra (Figure 5k) biome regions,. In spite of this, there are some spots in high and midlatitudes, which show more $\mathrm{C}$ release to the atmosphere in ISAM-NC case than in ISAM-C case (Figure 4b), because in some regions the rate of release of plantavailable $\mathrm{N}$ from soils reduces over time and heterotrophic respiration rates of $\mathrm{C}$ become larger than the climate-driven $\mathrm{C}$ sequestration rates in vegetation. Our modeling results suggest that there is no indirect $\mathrm{N}$ mineralization feedback effect in tropical regions (Figure 51), in particular tropical forests (Figure $5 \mathrm{~g}$ ).

[25] Driven by the combined effect of climate (temperature and precipitation) and $\left[\mathrm{CO}_{2}\right]$, model results exhibit carbon sink rates that remain approximately unchanged between 1900 and 1945 and then increases throughout the remainder of the 20th century for both the ISAM-C and ISAM-NC cases with carbon exchange variability driven largely by climate variability and the carbon sink driven largely by $\mathrm{CO}_{2}$ fertilization (Figure 2c). It is important to note that there are interactions between the effects of $\mathrm{CO}_{2}$ and climate evident in the results of both ISAM-C and ISAM-NC (Table 2). For example, the combined effect of $\mathrm{CO}_{2}$ and climate is not the same as that estimated by simply adding the $\mathrm{CO}_{2}$ effect to the climate effect in the results of either ISAM-C and ISAM-NC. For the ISAM-C case, the terrestrial $\mathrm{C}$ uptake estimated by the sum of the $\mathrm{CO}_{2}$-driven result and climate-driven result is greater than that of the model driven by both $\mathrm{CO}_{2}$ and climate, which is consistent with model results assessed by the IPCC that indicate that less carbon is stored in terrestrial ecosystems and soils because the larger amount of carbon stored due to $\mathrm{CO}_{2}$ fertilization leads to more respiration than would be predicted by the individual factors alone [Denman et al., 2007]. In contrast, for the ISAM-NC, the terrestrial C uptake predicted by the sum of the $\mathrm{CO}_{2}$-driven and climate-driven results is less than that of the model driven by both $\mathrm{CO}_{2}$ and Climate. This is because warming leads to higher $\mathrm{N}$ availability whereas enhanced $\mathrm{CO}_{2}$ leads to even higher $\mathrm{C}$ availability resulting in more $\mathrm{C}$ uptake than would be predicted by summing the effects. The vegetation and soil $\mathrm{C}$ and $\mathrm{N}$ stocks for the combined cases $\left(\mathrm{CO}_{2}\right.$ and Climate) are shown in Figures $3 \mathrm{e}$ and $3 \mathrm{f}$.

[26] Figure 4c shows the net terrestrial $\mathrm{C}$ flux difference (ISAM-NC minus ISAM-C) for the 1990s as a result of two compensating effects: the limiting effect of $\mathrm{N}$ under increasing $\left[\mathrm{CO}_{2}\right]$ and the indirect $\mathrm{N}$ fertilization effect driven by climate change (temperature and precipitation). The ISAM simulations show an increased sink for $\mathrm{C}$ in northern highlatitude regions while there is a increased source of $\mathrm{C}$ in temperate midlatitudes when elevated $\left[\mathrm{CO}_{2}\right]$ is considered concomitantly with changes in climate (Figure 4c).

[27] The impact of increased $\mathrm{N}$ deposition on terrestrial $\mathrm{C}$ fluxes is shown in Figure 2d. There is no change in $\mathrm{C}$ fluxes for ISAM-C despite additional $\mathrm{N}$ input through deposition since the $\mathrm{N}$ cycle is not coupled to carbon cycle in ISAM-C. Increased $\mathrm{N}$ availability driven by deposition could stimulate the accumulation of additional $\mathrm{C}$ in terrestrial ecosystems [Nadelhoffer et al., 1999], mainly in forest biomes, because of the high $\mathrm{C}: \mathrm{N}$ ratios and the large $\mathrm{C}$ storage capacity [Holland et al., 1997]. Our model results show that the $\mathrm{C}$ and $\mathrm{N}$ storage due to $\mathrm{N}$ deposition increases in vegetation and soils from 1900 to 2000 (Figures 3g and $3 \mathrm{~h}$ ). As a result of this, the carbon sink rate estimated by the ISAM-NC model increases over time (Figure 2d). The majority of the $\mathrm{N}$ deposition occurs in the forests of Northern Hemisphere temperate zones. As a result, nearly all 1990s global C sink due to $\mathrm{N}$ deposition occurs in this region, particularly in the eastern United States, Europe, China and India (Figure 4d). Our modeling results suggest that increased $\mathrm{N}$ deposition over the 1990s caused a $0.26 \mathrm{PgC} \mathrm{yr}^{-1}$ accumulation rate mainly in forest ecosystems (Table 2). Our model results are at the lower end of the range of values $\left(0.1-2.3{\left.\mathrm{PgC} \mathrm{yr}^{-1}\right)}^{-1}\right.$ estimated by other studies [Peterson and Melillo, 1985; Townsend et al., 1996; Holland et al., 1997; Nadelhoffer et al., 1999; Churkina et al., 2007]. These results are supported by the finding of Nadelhoffer et al. [1999], which used the evidence of $15 \mathrm{~N}$-tracer data from 9 forests to show that the effect of increased $\mathrm{N}$ deposition on temperate forests $\mathrm{C}$ seques-

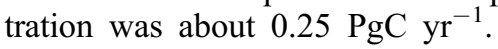

[28] The calculated net terrestrial $\mathrm{C}$ fluxes due to LCLUC over the period 1900-2000 for cases ISAM-NC and ISAM-C are shown in Figure 2e. Both cases ISAM-C and ISAM-NC result in land use change net emissions smaller than the commonly cited range [Denman et al., 2007]; this is because (1) the input data set used in this study by Ramankutty and Foley [1998, 1999], which does not 
include pasture conversions, rotational forestry, fires, and urbanization, results in LCLUC emissions toward the low end of the range [Jain and Yang, 2005]; and (2) the estimated LCLUC effect in this study does not include the interactive effects with changes in other environmental factors that are normally included implicitly in other calculations of LCLUC effects. In the short term, the conversion of naturally occurring vegetation to croplands increases litter input to the soil that increases the overall soil decomposition rate to enhance the mineralization of $\mathrm{N}$ available for plant productivity. In the longer term, cropland soils lose $\mathrm{N}$ through agricultural harvest. While this loss of $\mathrm{N}$ does not generally decrease agricultural productivity because of the wide use of fertilizer $\mathrm{N}$ application, the loss of $\mathrm{N}$ from soils does affect forest regrowth on former agriculture land and on reforested land. For ISAM-NC simulations the forest regrowth and $\mathrm{C}$ accumulation is increasingly reduced in comparison to the ISAM-C simulation in the late 20th century (Figure 2e) in regions where $\mathrm{N}$ is a limiting nutrient, particularly in the southeastern United States (Figure 4e). During the 1990s global net $\mathrm{C}$ uptake due to land cover change estimated by ISAM-NC is $0.08 \mathrm{PgC} \mathrm{yr}^{-1}$ less than that estimated by ISAM-C (Table 2). It is interesting to note that the LCLUC influenced changes in vegetation and soil carbon stocks over the period 1900-2000 for the ISAM-C and ISAM-NC cases are quite similar, although the estimated responses of soil carbon are quit different from vegetation carbon stocks in these cases (Figure 3i). With changes in LCLUC over the period 1900-2000, the soil carbon stocks remained approximately constant, whereas global vegetation carbon stocks decreased by about $60 \mathrm{PgC}$ (Figure 3i). The ISAM estimated vegetation and soil $\mathrm{N}$ stocks for ISAM-NC case show generally a decreasing trend with a larger decrease in vegetation than soil $\mathrm{N}$ (Figure 3j).

[29] When all factors are considered simultaneously, the comparison of the ISAM-NC and ISAM-C simulations indicate small differences occur between the estimated carbon fluxes over the time period 1900-2000 (Figure 2f). The net changes in $\mathrm{C}$ fluctuate around zero prior to 1950 and then they become positive until 1960; that is, C fluxes become net source for $\left[\mathrm{CO}_{2}\right]$. Thereafter the $\mathrm{C}$ sinks grow in both cases. The model simulations of concurrent effect of all variables indicates that on the influence of the terrestrial $\mathrm{N}$ cycle in moderating the $\mathrm{CO}_{2}$ fertilization, climate, $\mathrm{N}$ inputs and LCLUC effects on terrestrial carbon storage estimated by ISAM-NC approximately cancel (Figure 2f) in comparison to the ISAM-C simulation throughout the 20th century. The terrestrial C sink during the 1990s simulated by ISAMNC was only $0.09 \mathrm{Pg} \mathrm{C} \mathrm{yr}^{-1}$ higher than the sink simulated by ISAM-C (Table 2). Although the difference between the two simulations is small in the 1990 s, there are substantial differences in the spatial distribution of the exchange of $\mathrm{CO}_{2}$ between the two simulations (Figure 4f). While both simulations estimate sink activity across all biomes and latitude bands (Figures 6a-6f), the consideration of $\mathrm{N}$ dynamics results in a greater sink of $\mathrm{CO}_{2}$ in northern high latitudes, particularly in boreal regions (Figure 6c) and a smaller sink of $\mathrm{CO}_{2}$ in south temperate latitudes (Figure 6b) primarily located in the southeastern United States (Figure 4f). The greater sink in high latitudes is primarily associated with climate effects (Figure $4 \mathrm{~b}$ ) and the smaller sink of $\mathrm{CO}_{2}$ in the southeastern United States caused by $\mathrm{N}$ limitation associated with both $\mathrm{CO}_{2}$ fertilization (Figure $4 \mathrm{a}$ ) and forest regrowth (Figure 4e).

\section{Conclusions}

[30] Results of this study suggest that responses of available $\mathrm{N}$ in terrestrial ecosystems to global environmental changes have not significantly affected the amount of terrestrial $\mathrm{C}$ sequestration over the 20th century, but these $\mathrm{N}$ responses have a strong influence on the spatial distribution of predicted $\mathrm{C}$ sequestration. Simulation results suggest that $\mathrm{N}$ was in increasingly short supply in temperate and boreal forest regions, particularly in moist temperate regions during the late 20th century, which limited the sink for $\left[\mathrm{CO}_{2}\right]$ in these regions, but $\mathrm{N}$ deposition and increased $\mathrm{N}$ mineralization due to climate change led to increased $\mathrm{N}$ availability and higher productivity over the 20th century that nearly eliminates the climate-driven $\mathrm{C}$ source from this decomposition in the case where the $\mathrm{C}$ fluxes were less affected by $\mathrm{N}$ dynamics. The response of $\mathrm{C}$ sequestration to increased $\mathrm{N}$ deposition and climate warming in temperate regions was not strong enough to overcome the effects of the $\mathrm{N}$ cycle in limiting $\mathrm{CO}_{2}$ fertilization response and forest regrowth. In contrast, the results suggest that $\mathrm{N}$ dynamics enhanced the $\mathrm{CO}_{2}$ sink in boreal regions because climate warming enhanced the availability of mineral $\mathrm{N}$ in northern high-latitude ecosystems. Thus, our results indicated that the effect of global environmental change on the terrestrial C sinks is both temporally and spatially variable as are the influences of changing $\mathrm{N}$ availability.

[31] Unlike Thornton et al. [2007] who concluded that C cycle models that do not consider interactions with the $\mathrm{N}$ cycle will overestimate terrestrial $\mathrm{C}$ sequestration during the 20th century [i.e., Thornton et al., 2007], our analysis using ISAM-NC and ISAM-C estimates approximately the same total global amount of $\mathrm{C}$ uptake during the entire 20th century regardless of the consideration of $\mathrm{N}$ cycle dynamics. One reason may be that Thornton et al. estimated a stronger nitrogen constraint on $\mathrm{CO}_{2}$ fertilization than estimated in our study. In their study, the mean uptake due to increasing $\mathrm{CO} 2$ concentrations estimated by their carbon and nitrogen interactive model (as in our case NC) is $74 \%$ lower than that estimated by their carbon-only model (as in our case C). In our study, the ISAM-NC estimates a mean uptake due to increasing $\mathrm{CO}_{2}$ concentrations that is only $24 \%$ lower than the ISAM-C.

[32] While ISAM's net terrestrial carbon sink of 2.57 PgC $\mathrm{yr}^{-1}$ during the 1990s for the case with a fully dynamic $\mathrm{N}$ cycle driven by all modeled environmental factors is outside the range $\left(-1.0 \pm 0.6 \mathrm{PgC} \mathrm{yr}^{-1}\right)$ of those estimated by IPCC's Fourth Assessment Report [Denman et al., 2007] (Table 2), there are substantial uncertainties in the responses of the model to the factors considered. Furthermore, there are other issues that affect terrestrial $\mathrm{C}$ storage that the analysis did not consider, e.g., land use change that may not have been captured in the data sets used, the effects of tropospheric ozone [Felzer et al., 2007], forest fires [Balshi et al., 2007], and insect outbreaks [Kurz et al., 2008] to 
identify just a few. Nonetheless, this study indicates that interactions between the $\mathrm{N}$ and the $\mathrm{C}$ cycles are currently playing an important role in influencing terrestrial $\mathrm{CO}_{2}$ sinks at regional scales, and therefore need to be considered in coupled C-climate system models.

33] Acknowledgments. We acknowledge Victoria Wittig and Daniel Hayes whose comments led to significant improvements in this manuscript We thank F. Dentener for providing us the $\mathrm{N}$ deposition data. We also acknowledge the financial support of the National Aeronautics and Space Administration Land Cover and Land Use Change Program (NNX08AK75G)

\section{References}

Balshi, M. S., et al. (2007), The role of historical fire disturbance in the carbon dynamics of the pan-boreal region: A process-based analysis, J. Geophys. Res., 112, G02029, doi:10.1029/2006JG000380.

Bradbury, N. J., A. P. Whitmore, P. B. S. Hart, and D. S. Jenkinson (1993), Modelling the fate of nitrogen in crop and soil in the years following application of $15 \mathrm{~N}$-labelled fertilizer to winter wheat, J. Agric. Sci., 121, 363-379, doi:10.1017/S0021859600085567.

Brovkin, V., M. Claussen, E. Driesschaert, T. Fichefet, D. Kicklighter, M. F. Loutre, H. D. Matthews, N. Ramankutty, M. Schaeffer, and A. Sokolov (2006), Biogeophysical effects of historical land cover changes simulated by six earth system models of intermediate complexity, Clim. Dyn., 26(6), 587-600, doi:10.1007/s00382-005-0092-6.

Canadell, J. G., D. E. Pataki, R. Gifford, R. A. Houghton, Y. Luo, M. R. Raupach, P. Smith, and W. Steffen (2007), Saturation of the terrestrial carbon sink, in Terrestrial Ecosystems in a Changing World, edited by J. G. Canadell, D. E. Pataki, and L. F. Pitelka, pp. 59-78, IGBP Ser., Springer, Berlin.

Churkina, G., K. Trusilova, M. Vetter, and F. Dentener (2007), Contributions of nitrogen deposition and forest regrowth to terrestrial carbon uptake, Carbon Balance Manage., 2, 5, doi:10.1186/1750-0680-2-5.

Cleveland, C. C., A. R. Townsend, D. S. Schimel, H. Fisher, R. W. Howarth, L. O. Hedin, S. S. Perakis, E. F. Latty, J. C. Von Fischer, and A. Elseroad (1999), Global patterns of terrestrial biological nitrogen $\left(\mathrm{N}_{2}\right)$ fixation in natural ecosystems, Global Biogeochem. Cycles, 13(2), 623-645, doi:10.1029/1999GB900014.

Coleman, K., and D. S. Jenkinson (1999), ROTHC-26.3-A Model for the Turnover of Carbon in Soil: Model Description and Windows Users Guide, 45 pp., Lawes Agric. Trust, Harpenden, U. K.

Cramer, W., et al. (1999), Comparing global models of terrestrial net primary productivity (NPP): Overview and key results, Global Change Biol., 5, 1-15.

Davidson, E. A., et al. (2004), Nitrogen and phosphorus limitation of biomass growth in a tropical secondary forest, Ecol. Appl., 14(4), 150-163, doi:10.1890/01-6006.

Denman, K. L., et al. (2007), Couplings Between Changes in the Climate System and Biogeochemistry, in Climate Change 2007: The Physical Science Basis. Contribution of Working Group I to the Fourth Assessment Report of the Intergovernmental Panel on Climate Change, edited by S. Solomon et al., pp. 499-587, Cambridge Univ. Press, Cambridge, U. K.

Felzer, B. S., T. Cronin, J. M. Reilly, J. M. Melillo, and X. Wang (2007), Impacts of ozone on trees and crops, C. R. Geosci., 339, 784-798, doi:10.1016/j.crte.2007.08.008.

Friedlingstein, P., et al. (2006), Climate-carbon cycle feedback analysis: Results from the C4MIP model intercomparison, J. Clim., 19, $3337-$ 3353, doi:10.1175/JCLI3800.1

Gallardo, A., and W. H. Schlesinger (1992), Carbon and nitrogen limitation of soils microbial biomass in desert ecosystems, Biogeochemistry, 18, 117, doi:10.1007/BF00000423

Galloway, J. N., et al. (2004), Nitrogen cycles: Past, present, and future, Biogeochemistry, 70(2), 153-226, doi:10.1007/s10533-004-0370-0.

Harrington, R. A., J. H. Fownes, and P. M. Vitousek (2001), Production and resource use efficiencies in $\mathrm{N}$ - and P-limited tropical forests: A comparison of responses to long-term fertilization, Ecosystems, 4, 646-657, doi:10.1007/s10021-001-0034-z.

Haxeltine, A., and I. C. Prentice (1996), BIOME3: An equilibrium terrestrial biosphere model based on ecophysiological constraints, resource availability, and competition among plant functional type, Global Biogeochem. Cycles, 10, 693-709, doi:10.1029/96GB02344.

Holland, E. A., et al. (1997), Variations in the predicted spatial distribution of atmospheric nitrogen deposition and their impact on carbon uptake by terrestrial ecosystems, J. Geophys. Res., 102(D13), 15,849-15,866, doi:10.1029/96JD03164.
Holland, E. A., B. H. Braswell, J. Sulzmann, and J.-F. Lamarque (2005), Nitrogen deposition onto the United States and western Europe: Synthesis of observations and models, Ecol. Appl., 15, 38-57, doi:10.1890/03-5162.

Hungate, B. A., J. S. Dukes, M. R. Shaw, Y. Q. Luo, and C. B. Field (2003), Nitrogen and climate change, Science, 302, 1512-1513, doi:10.1126/ science. 1091390.

Hyvönen, R., et al. (2007), The likely impact of elevated $\left[\mathrm{CO}_{2}\right]$, nitrogen deposition, increased temperature and management on carbon sequestration in temperate and boreal forest ecosystems: A literature review, New Phytol., 173, 463-480, doi:10.1111/j.1469-8137.2007.01967.x.

Jain, A. K., and X. Yang (2005), Modeling the effects of two different land cover change data sets on the carbon stocks of plants and soils in concert With $\mathrm{CO}_{2}$ and climate change, Global Biogeochem. Cycles, 19, GB2015, doi:10.1029/2004GB002349.

Jain, A. K., H. S. Kheshgi, and D. J. Wuebbles (1996), A globally aggregated reconstruction of cycles of carbon and its isotopes, Tellus, Ser. B, 48(4), 583-600, doi:10.1034/j.1600-0889.1996.t01-1-00012.x.

Jenkinson, D. (1990), The turnover of organic carbon and nitrogen in soil, Philos. Trans. R. Soc. London, Ser. B, 329(1255), 361-367, doi:10.1098/ rstb.1990.0177.

Keeling, C. D., and T. P. Whorf (2007), Atmospheric $\mathrm{CO}_{2}$ records from sites in the SIO air sampling network, in Trends: A Compendium of Data on Global Change, Carbon Dioxide Inf. Anal. Cent., Oak Ridge Natl. Lab., U.S. Dept. of Energy, Oak Ridge, Tenn. (Available at http://cdiac. ornl.gov/trends/co2/sio-keel.html)

Kheshgi, H. S., A. K. Jain, and D. J. Wuebbles (1996), Accounting for the missing carbon-sink with the $\mathrm{CO}_{2}$-fertilization effect, Clim. Change, 33(1), 31-62, doi:10.1007/BF00140512.

Kicklighter, D. W., et al. (1999), A first-order analysis of the potential role of $\mathrm{CO}_{2}$ fertilization to affect the global carbon budget: A comparison of four terrestrial biosphere models, Tellus, Ser. B, 51, 343-366.

King, A. W., W. R. Emanuel, S. D. Wullschleger, and W. M. Post (1995), In search of the missing carbon sink: A model of terrestrial biospheric response to land-use change and atmospheric $\mathrm{CO}_{2}$, Tellus, Ser. B, 47(4), 501-519, doi:10.1034/j.1600-0889.47.issue4.9.x.

Kurz, W. A., C. C. Dymond, G. Stinson, G. J. Rampley, E. T. Neilson, A. L. Carroll, T. Ebata, and L. Safranyik (2008), Mountain pine beetle and forest carbon feedback to climate change, Nature, 452, 987-990, doi: $10.1038 /$ nature 06777 .

Lelieveld, J., and F. J. Dentener (2000), What controls tropospheric ozone? J. Geophys. Res., 105(D3), 3531-3551, doi:10.1029/1999JD901011.

Long-Term Intersite Decomposition Experiment Team (LIDET) (1995), Long-Term Intersite Decomposition Experiment Team: Meeting the challenge of long-term, broad scale ecological experiments, Publ. 19, LTER Network Off., Seattle, Wash.

Loveland, T. R., and A. S. Belward (1997), The IGBP-DIS global $1 \mathrm{~km}$ land cover data set, DISCover: first results, Int. J. Remote Sens., 18, 3289-3295, doi:10.1080/014311697217099.

Luo, Y., et al. (2004), Progressive nitrogen limitation of ecosystem responses to rising atmospheric $\mathrm{CO}_{2}$ concentration, BioScience, 54 731-739, doi:10.1641/0006-568(2004)054[0731:PNLOER]2.0.CO;2.

Luo, Y., D. Hui, and D. Zhang (2006), Elevated $\mathrm{CO}_{2}$ stimulates net accumulations of carbon and nitrogen in land ecosystems: A meta-analysis, Ecology, 87, 53-63, doi:10.1890/04-1724.

McGuire, A. D., J. M. Melillo, L. A. Joyce, D. W. Kicklighter, A. L. Grace, B. Moore III, and C. J. Vorosmarty (1992), Interactions between carbon and nitrogen dynamics in estimating net primary productivity for potential vegetation in North America, Global Biogeochem. Cycles, 6, $101-$ 124, doi:10.1029/92GB00219.

McGuire, A. D., J. M. Melillo, D. W. Kicklighter, Y. Pan, X. Xiao, J. Helfrich, B. Moore III, C. J. Vorosmarty, and A. L. Schloss (1997), Equilibrium responses of global net primary production and carbon storage to doubled atmospheric carbon dioxide: Sensitivity to changes in vegetation nitrogen concentration, Global Biogeochem. Cycles, 11, 173-189, doi:10.1029/ 97GB00059.

McGuire, A. D., et al. (2001), Carbon balance of the terrestrial biosphere in the twentieth century: Analyses of $\mathrm{CO}_{2}$, climate and land use effects with four process-based ecosystem models, Global Biogeochem. Cycles, 15 183-206, doi:10.1029/2000GB001298.

McGuire, A. D., et al. (2007), Responses of high latitude ecosystems to global change: Potential consequences for the climate system, in Terrestrial Ecosystems in a Changing World, edited by J. G. Canadell, D. E. Pataki, and L. F. Pitelka, pp. 297-310, IGBP Ser., Springer, Berlin.

Mitchell, T. D., and P. D. Jones (2005), A improved method of constructing a database of monthly climate observations and associated high-resolution grids, Int. J. Climatol., 25, 693-712, doi:10.1002/joc.1181.

Moorhead, D., W. Currie, E. Rastetter, W. Parton, and M. Harmon (1999), Climate and litter quality controls on decomposition: An analysis of 
modeling approaches, Global Biogeochem. Cycles, 13, 575-590, doi:10.1029/1998GB900014.

Nadelhoffer, K. J., B. A. Emmett, and P. Gundersen (1999), Nitrogen deposition makes a minor contribution to carbon sequestration in temperate forests, Nature, 398, 145-148, doi:10.1038/18205.

Parton, W. J., and P. E. Rasmussen (1994), Long-term effects of crop management in wheat-fallow: II. CENTURY model simulations, Soil Sci. Soc. Am. J., 58, 530-536.

Parton, W. J., D. Schimel, C. Cole, and D. Ojima (1987), Analysis of factors controlling soil organic levels of grasslands in the Great Plains, Soil Sci. Soc. Am. J., 51, 1173-1179.

Parton, W., et al. (2007), Global scale similarities in nitrogen release patterns during long-term decomposition, Science, 315, 361-364, doi:10.1126/science.1134853.

Pastor, J., and W. Post (1985), Development of a linked forest productivity-soil process model, ORNL TM-9519, Oak Ridge Natl. Lab., Oak Ridge, Tenn

Paul, K. I., and P. J. Polglase (2004), Calibration of the RothC model to turnover of soil carbon under eucalypts and pines, Aust. J. Soil Res., 42, 883-895, doi:10.1071/SR04025.

Peterson, B. J., and J. M. Melillo (1985), The potential storage of carbon caused by eutrophication of the biosphere, Tellus, 37, 117-127.

Prentice, I. C., et al. (2001), The carbon cycle and atmospheric carbon dioxide Climate Change 2001: The Scientific Basis. Contribution of Working Group I to the Third Assessment Report of the Intergovernmental Panel on Climate Change, edited by J. T. Houghton et al., pp. 183237, Cambridge Univ. Press, Cambridge, U. K.

Raich, J., E. Rastetter, J. Melillo, D. W. Kicklighter, P. A. Steudler, B. Peterson, A. Grace, B. Moore III, and C. Vorosmarty (1991), Potentia net primary productivity in South America: Application of a global model, Ecol. Appl., 1(4), 399-429, doi:10.2307/1941899.

Ramankutty, N., and J. Foley (1998), Characterizing patterns of global land use: An analysis of global croplands data, Global Biogeochem. Cycles, 12, 667-685, doi:10.1029/98GB02512.

Ramankutty, N., and J. A. Foley (1999), Estimating historical changes in global land cover: Croplands from 1700 to 1992, Global Biogeochem. Cycles, 13, 997-1027, doi:10.1029/1999GB900046.

Schimel, D. S., B. Braswell, R. McKeown, D. Ojima, W. Parton, and W. Pulliam (1996), Climate and nitrogen controls on the geography and timescales of terrestrial biogeochemical cycling, Global Biogeochem. Cycles, 10, 677-692, doi:10.1029/96GB01524.

Shaver, G. R., W. D. Billings, F. S. Chapin, A. E. Giblin, K. J. Nadlehoffer, W. C. Oechel, and E. B. Rastetter (1992), Global change and the carbon balance of arctic ecosystems, BioScience, 42, 433-441, doi:10.2307/ 1311862 .
Sokolov, A. P., D. W. Kicklighter, J. M. Melillo, B. Felzer, C. A. Schlosser, and T. W. Cronin (2008), Consequences of considering carbon/nitrogen interactions on the feedbacks between climate and the terrestrial carbon cycle, J. Clim., 21, 3776-3796, doi:10.1175/2008JCLI2038.1

Thornton, P., J. F. Lamarque, N. A. Rosenbloom, and N. M. Mahowald (2007), Inclusion of carbon-nitrogen feedback fundamentally changes response of land carbon model to $\mathrm{CO}_{2}$ fertilization and climate variability, Global Biogeochem. Cycles, 21, GB4018, doi:10.1029/2006GB002868.

Thornton, P. E., S. C. Doney, K. Lindsay, J. K. Moore, N. Mahowald, J. T. Randerson, I. Fung, J.-F. Lamarque, J. J. Feddema, and Y.-H. Lee (2009), Carbon-nitrogen interactions regulate climate-carbon cycle feedbacks: Results from an atmosphere-ocean general circulation model, Biogeosci. Discuss., 6, 3303-3354.

Townsend, A. R., B. H. Braswell, E. A. Holland, and J. E. Penner (1996), Spatial and temporal patterns in potential terrestrial carbon storage resulting from deposition of fossil fuel derived nitrogen, Ecol. Appl., 6 , 806-814, doi:10.2307/2269486.

Vitousek, P. M., and R. W. Howarth (1991), Nitrogen limitation on land and in the sea: How can it occur?, Biogeochemistry, 13, 87-115, doi:10.1007/BF00002772.

Yang, X., V. Wittig, A. K. Jain, and W. M. Post (2009), Integration of nitrogen cycle dynamics into the Integrated Science Assessment Model for the study of terrestrial ecosystem responses to global change, Global Biogeochem. Cycles, 23, GB4029, doi:10.1029/2009GB003474.

Yates, L. R., P. W. Rundel, R. Sylvester-Bradely, and R. E. Cisternas (1982), Report of the work group on savannas and shrublands, Plant Soil, 67, 409-413, doi:10.1007/BF02182790.

Zobler, L. (1999), Global Soil Types, 1-Degree Grid (Zobler), data set, Distrib. Active Arch. Cent., Oak Ridge Natl. Lab., Oak Ridge, Tenn.

A. Jain and X. Yang, Department of Atmospheric Sciences, University of Illinois at Urbana-Champaign, Urbana, IL 61801, USA. (jain1@uiuc.edu)

H. Kheshgi, ExxonMobil Research and Engineering Company, Annandale, NJ 08801, USA

D. Kicklighter, Marine Biological Laboratory, Woods Hole, MA 02543, USA.

A. D. McGuire, U.S. Geological Survey, Alaska Cooperative Fish and Wildlife Research Unit, University of Alaska Fairbanks, Fairbanks, AK 99775, USA.

W. Post, Environmental Sciences Division, Oak Ridge National Laboratory, Oak Ridge, TN 37831, USA. 